\title{
MedienPädagogik
}

www. medienpaed.com

Zeitschrift für

Theorie und Praxis

der Medienbildung

ISSN 1424-3636

Themenheft Nr. 24: Educational Media Ecologies

\section{Media Form School - A Plea for Expanded Action Orientations and Reflective Perspectives}

Theo Hug

\begin{abstract}
Media-related rhetoric plays a remarkable role in the context of school (re)forms, whether the arguments are euphoric or skeptical about media. On the one hand, there are reminders of the need for sheltered spaces and developmental tasks for children and adolescents, for the detailed differentiation of literacy as an educational task, or for maximizing equal opportunities. In these cases, media are mostly seen as means of learning, education or development advancement. On the other hand, debates also deal with the development of adequate infrastructures for learning and teaching with more-or-less «new» media, media-based school development projects, or the implementation of e-learning strategies. Here it is striking that, on closer observation, innovative efforts frequently turn out to be structural-conservative administrative measures which fail to address the contemporary media-anthropological, mediaepistemological and media-cultural challenges. The focus of the article is on schoolbased monopolies of education and information. It explores expanded perspectives of reflection and action-orientation in light of the theory of medial forms.
\end{abstract}

\section{Introduction}

That media (could) play an increased role in the context of school teaching and learning is lamented by some, hoped for by others, and occasionally ignored. That media are generally significant in the processes of growing up, developing identity and value-orientations, and in everyday aesthetics, and in the forming of self- and world-references (Selbst- und Weltbezüge) is also commonly affirmed. To put it briefly and abstractly: It is nowadays beyond question that media are involved in some respects in creating realities and shaping communication processes. In this general sense they are definitely granted constructive traits, even and especially when the medial influences and effects are assessed to be problematic or destructive (see Hug 2011a). However, when it comes to describing what constitutes this significance, how it comes about, and how it is to be evaluated, opinions differ widely.

One difficulty in this is that both education and media studies use many different definitions and notions of media, making intra- and interdisciplinary communication

1 Translated by Mag. Susanne Toelken-Mettauer.

Hug, Theo. 2014. «Media Form School - A Plea for Expanded Action Orientations and Reflective Perspectives.» MedienPädagogik 24 (25. Sept.): 114-135. https://doi.org/10.21240/mpaed/24/2014.09.25.X. 
a challenge. Similarly, terms like 〈school,, 〈learnings or «education〉 are used in very diverse ways, and they correspond with partly incommensurable forms of theoretical conceptualization and practical application.

In addition, everyday uses may touch upon scientific discourses in the sense that everyone-including academics- has their own background in terms of upbringing, schooling, media use, (gaps in) learning, etc., in general without systematically and consistently (self-)reflexively inquiring about the relevance of these experiential contexts for institutionalized research processes. By this I do not mean that every articulated context of experience should withstand a conceptual analysis based on the philosophy of education, media or language, or even have been subject to psychoanalysis. Neither levels of conceptual accuracy nor degrees of psycho- or socio-dynamic clarification represent values as such. Correspondent demands for clarification make different sense in different contexts. Also, values that have been found to be important in one context cannot be meaningfully defined once and for all. However, they can be justified based on situation and context by the actors involved, and made valuable depending on skill, scope of action, and the given constellation of actors and powers.

In both everyday and scientific discursive contexts, we find media-phobic and media-philic points of view but also others that matter-of-factly deliberate and differentiate. I believe it is important not to lose sight of the affect-logical ${ }^{2}$ dynamics in this connection (see Ciompi 1997), especially since it is easy to notice recurrent patterns of argumentation in the wake of historical and contemporary media dynamics (see Rusch 2007, 44; Leschke 2013). One of the challenges lies in the development of individual, institutional or meta-theoretically oriented forms of self-reflection, both in regard to affect-logical dimensions of media issues but also as an element of pedagogical professionalism (see Hierdeis 2009) under current conditions of medialization.

Another challenge consists in overcoming (self-)restrictive perspectives when it comes to media and school. In the following, two examples will serve to illustrate how discursive constraints in school pedagogy and the technology of teaching can/could be resolved. After some initial considerations, the examples of concrete poetry and media activism are used to question the matter-of-fact handling of linguistic and action-oriented forms. In conceptual terms, it will be shown how the theory of medial forms (Leschke 2010) is relevant for discourses of educational and learning theory.

2 For a brief explanation of the concept of «affect-logic see Ciompi (n. d.). The concept was introduced in the early 80s. It refers to interactive dynamics between feeling and thinking or emotion and cognition in a sense that affective elements show up in all cognitive processes («logic» in a broad sense) and elements of logic show in all emotional dynamics or affects. 


\section{Initial considerations}

For several years, media issues have increasingly found their way into schoolrelated discourses of learning, education and organizational development. In many countries experts are working on developing positions and recommendations for action related to current questions of media and education policy. ${ }^{3}$ Yet this does not mean that testimonies to the relevance of media and technological promises made in the context of education policy would go hand in hand with the prominent ranking of media-theoretical or media-pedagogical topics in grant programs or legal structural requirements. Concerning the situation in Austria, though there is no lack of rhetorical appeals to innovation (consider the slogans «NEW educator training ' and (NEW teacher training)), the relevant expert reports are all written in line with traditional views (see Härtel et al. 2010; Schnider et al. 2011). A supplementary expert report on the 'NEW teacher training (see Hopmann et al. 2010) may criticize this tradition in Austrian school teaching, "the assignment to fields of work is even today mostly based on organizational principles that essentially established themselves nationwide in the eighteenth and nineteenth centuries» (ibid., 4). However, when this same report discusses the transition from a «premodern matrix system to a modern, flexible school design» (ibid., 4), it does not explicitly take into account the role of media.

By and large, affirmations of the relevance of media in educational policy discourse correspond to consistently marginal positionings of media-related concerns. That questions about the order of the world, of knowledge, the societies, generations, sexes, etc. are always related to questions about the order of media often does not receive sufficient attention. The idea that media pedagogy is among the eligible «suitable areas of concentration» (Härtel et al. 2010, 48) for teacher training does not speak of an adequate understanding of the current requirements, just like the marginal reference to the use of «real and virtual places of learning» (ibid., 7) inside and outside of school or occasional links to ICT (ibid., 11, 19).

While in these reports, media issues are treated as optional pedagogical specializations, structural measures further contribute to the view that the occupation with digital media and new cultures of learning in school is largely optional. Even if the basic ordinances by the Ministry of Education, Art and Culture concerning «Holistic-creative learning culture in schools» and «Media education» (see bm:ukk 2009; bm:ukk 2012) contain important suggestions for reflection and organization, it remains up to the teachers and administrators to seize them.

Austria is relatively hesitant to pick up international initiatives which are dedicated to opening up education on different levels by using digital communication

3 For the German-speaking countries, consider the initiatives «No Education without Media» («Keine Bildung ohne Medien»; http://www.keine-bildung-ohne-medien.de/), «Media Education NOW» («Medienbildung JETZT!»; http://www.medienbildungjetzt.at/) and «eEducation» (http://www eeducation.at/). 
technologies, creative commons licenses and massive open online courses (moocs). For a few years, the labels Open Education (OE) and Open Educational Resources (OER) have been used for discussing developments in digital media (see for example Atkins 2007; Butcher et al. 2011). ${ }^{4}$ The reports mentioned do not contain these discourses, just as contemporary handbooks and encyclopedias on pedagogy and education also do not (see for instance McCulloch and Crook 2008; Tippelt and Schmidt 2010; Horn et al. 2011). Discourses that are critical of schools (see for example Blankertz 2013) are hardly any different. However, specific initiatives and projects 5 reveal that the OER movement has indeed arrived in German-speaking Europe and that forward-looking approaches are being developed. In particular, Michael Kerres and Richard Heinen have demonstrated with the cooperative project called «Edutags» how informationally closed and open ecosystems can be designed for the school-based use of learning resources (see Kerres/Heinen 2014).

Even if it is true that media issues have increasingly been discussed for a number of years in discourses of school pedagogy and the theory of learning and education, these discussions do not, or in some sub-discourses at best, pay attention to several current challenges, including:

- The role played by school, which is frequently, and more or less consistently, connected to specific diagnoses of the times and characterizations borrowed from social theory. In the process, the plurality of such diagnoses is seen as little of an issue as more basic questions about the ways «in which ssociology of mobilities» disrupts «sociology of the social as society»» (Urry 2000,4) or considerations After Society (Nach der Gesellschaft; Faßler 2009).

- Justifications of school types as institutions of society occur on micro-, meso- and macro-levels from different normative and descriptive-analytical perspectives. The theoretical approaches to school elaborate on and critique different tasks and social functions as well as arguments intrinsic to and beyond school structures. The possibility of justifications based on media theory is largely suppressed in these discursive contexts, with some exceptions (see Böhme 2006).

- Discourses of media epistemology and media anthropology follow these same lines. The variety of cultural attitudes in medialized life-worlds and the diverse ways that perceptions and areas of reality can be referenced make it necessary to clarify the modalities of referencing (Schmidt 1999, 134-139). Informational dynamics are changing in view of the dynamics of simultaneously «disappearing»

4 See http://www.unesco.org/new/en/communication-and-information/access-to-knowledge/open -educational-resources/.

5 Seeforinstancehttp://www.e-teaching.org/community/communityevents/onlinepodium/oer_schule _hochschule, http://www.eduhub.ch/community/special-interest-groups-sig/sig-open-educational -resources/, http://www.edutags.de/ or http:///3t.eu. 
and the «omnipresent» digital technologies, and due to questions about the relationship between the reality of experience and the experience of reality. Issues concerning the importance of «informational intelligence» (Faßler 2008), «automatisms» (Bublitz et al. 2010) and post-humanistic and post-anthropocentric approaches (see for example Braidotti 2013) for (media) education in general and school education in particular have so far rarely been taken up in discourses of school pedagogy.

These brief remarks on the initial situation show that, in light of the mediatic turn (Friesen and Hug 2009), work is pending on a number of relevant and elementary issues which go far beyond established educational-technological models of e-education, strategies of implementing e-learning in schools, and conventional approaches to standardizing media education in schools.

\section{Concrete poetry and media activism as occasions and links for expanded perspectives of school and media pedagogy}

There is no shortage of models and scenarios when it comes to the ways that digital media can be applied in contexts of school teaching and learning. ${ }^{6}$ As in the use of analog media and all kinds of teaching material, possibilities for thought and action are frequently taken up and explored only in a limited way. This affects, on the one hand, the systems of signs that are used more or less as a matter of course, and, on the other, the discourse on action orientations. Below I would like to clarify this by means of two examples.

\subsection{Considerations on the sound-image «Media f/Form School»}

The title of this article, "Media Form School», offers various possibilities for interpretation. One way of «listening to it suggests that media form the school, without mentioning how this happens. There is a wide range of direct and indirect potential influences that come into question, for example through developments in the entertainment industry and media economy, changes in media law, the effects of media socialization, the evolutionary dynamics of a media society, products of e-learning industries and new business models, innovative media formats and new forms of mobile media culture, the architecture of school buildings, the use of sign systems, changed perceptive modes and economies of attention, the use of medications, bio-political and bio-medial developments, administrative routines, etc. These and other media developments can be regarded as isolated phenomena or as an ensemble or context of interaction, as marginally or vitally relevant, as

\footnotetext{
6 See for example Hettinger (2008), the special issue on e-learning in schools ("E-Learning in der Schule») of the journal Zeitschrift für E-Learing 4(3), http://www.e-learning-zeitschrift org/03_2009/), or the information provided by the e-learning network eLSA (http://elsa20.schule .at) and the international Network for Mobile Learning Scenarios (see http://scenarios.london mobilelearning.net/).
} 
theoretically founded or a-theoretical, application-oriented or as intended to be free from purpose, glocal, regional or local, gladly, skeptically or desperately, etc. The particular focus and way of addressing the subject, as well as the degree of differentiation certainly open specific discursive and performative horizons whose meaning is normally not immediately clear. On closer examination, exactly those representations and problem statements which are all too "self-evident» turn out to be questionable.

In most cases, it will be possible to dedicate only a very limited amount of time and energy to the explication of presuppositions, starting points and methodical justifications. If we rate communicative processes highly and forms of strategic assertion or tactical conquest less so, then we should also explicitly spell out, no matter how provisionally, our understanding of the problem(s). For example, if the title of this article is to be illustrated in a chart (see Figure 1), it makes a difference how the interrelationship of these elements are to be understood: As an «interplay», not otherwise specified, of three broadly defined clusters of factors; as an interactive model of certain methods of teaching, media technologies and school types; or as a Venn diagram which should represent, summarily and logically, the specific suitability of tools of a learning platform for certain forms of working and learning in a concrete school. The list of options could easily be continued, but the ones mentioned show sufficiently that established modalities in illustration are no less dependent on context and in need of interpretation than phonetic similarities and differences of forms of linguistic articulation. The algorithmic content of the representation is less obvious. Those familiar with current applications of a commercial software package know that Figure 1 can be generated relatively simply and that the creative latitude of the program used is limited, and so they can easily reconstruct forms, choice of font and colors as well as layout of the individual parts of the diagram.?

At this point, I want to go one step further and bring into play a point of view which has not attracted much interest in school or media pedagogy. The openness of the title's phrasing may invite to pause and produce associations. And if associated areas of tension are depicted as in Figure 2, the resulting reading experience may be similar to Heinz Gappmayr's works of Konkretedichtung (concrete poetry), a little known genre. In the course of a reflexive contemplation of the text-image «Media Form School» (Figure 2), prevalent uses of the employed terms are made dynamic insofar as their ontologizing traits are addressed and manifold assignments of characteristics come into consideration. Through their layout, visual and conceptual

7 The argument could certainly be differentiated much further, for instance by means of overviews of visualization methods (see http://www.visual-literacy.org/periodic_table/periodic_table. $\mathrm{html}$ ), through considerations of diagrammatic presentation (see Bauer and Ernst 2010) or Peter Bexte's project on visual argumentation (see http://www.geisteswissenschaften.fu-berlin.de/v/ embodiedinformation/projects/index.html). 


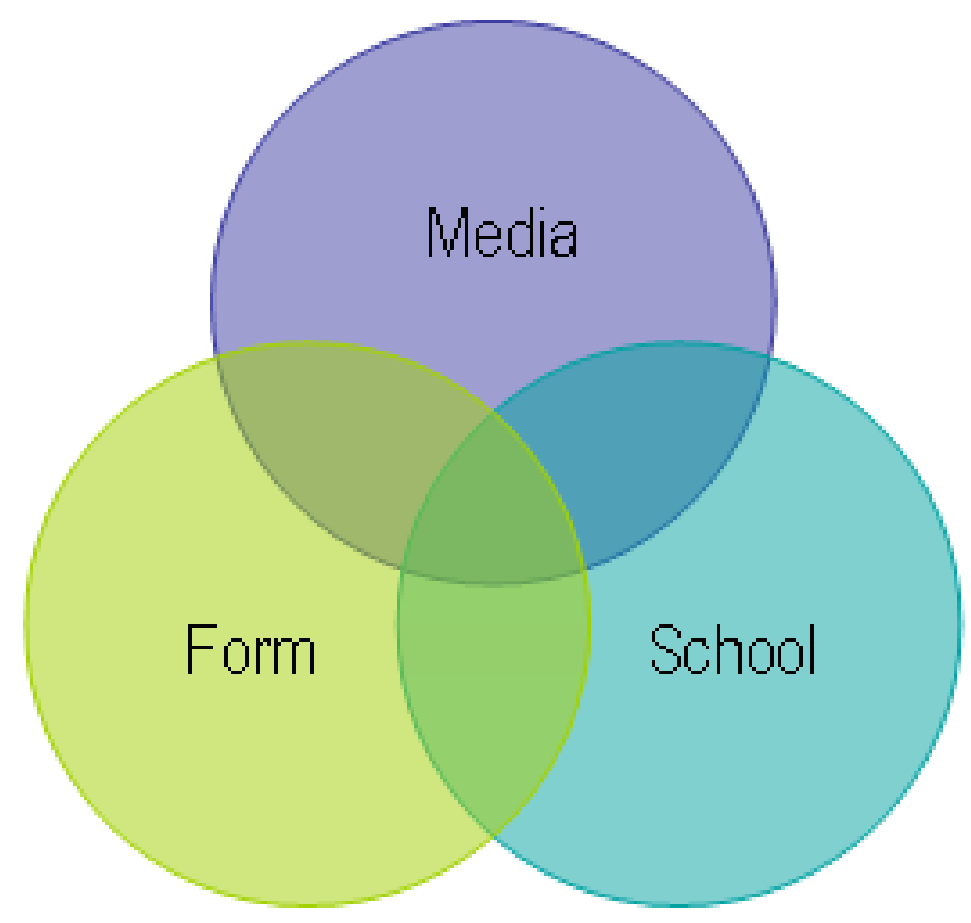

Figure 1: Chart «Media Form School» (illustration by the author).

elements create areas of tension which suggest a clarification of how both (visual and conceptual) levels relate to each other. In this context, attention may be paid to possible uses of concepts, their position in the framework of cultural symbols and societal contexts, rules of composition, connections to established aesthetic forms of representation, forms of figurative transfer, etc. (see Hug 2002, 21-23).

At this point, I want to go one step further and bring into play a point of view which has not attracted much interest in school or media pedagogy. The openness of the title's phrasing may invite to pause and produce associations. And if associated areas of tension are depicted as in Figure 2, the resulting reading experience may be similar to Heinz Gappmayr's works of Konkretedichtung (concrete poetry), a little known genre. In the course of a reflexive contemplation of the text-image «Media Form School» (Figure 2), prevalent uses of the employed terms are made dynamic insofar as their ontologizing traits are addressed and manifold assignments of characteristics come into consideration. Through their layout, visual and conceptual elements create areas of tension which suggest a clarification of how both (visual and conceptual) levels relate to each other. In this context, attention may be paid to possible uses of concepts, their position in the framework of cultural symbols and societal contexts, rules of composition, connections to established aesthetic forms of representation, forms of figurative transfer, etc. (see Hug 2002, 21-23). 


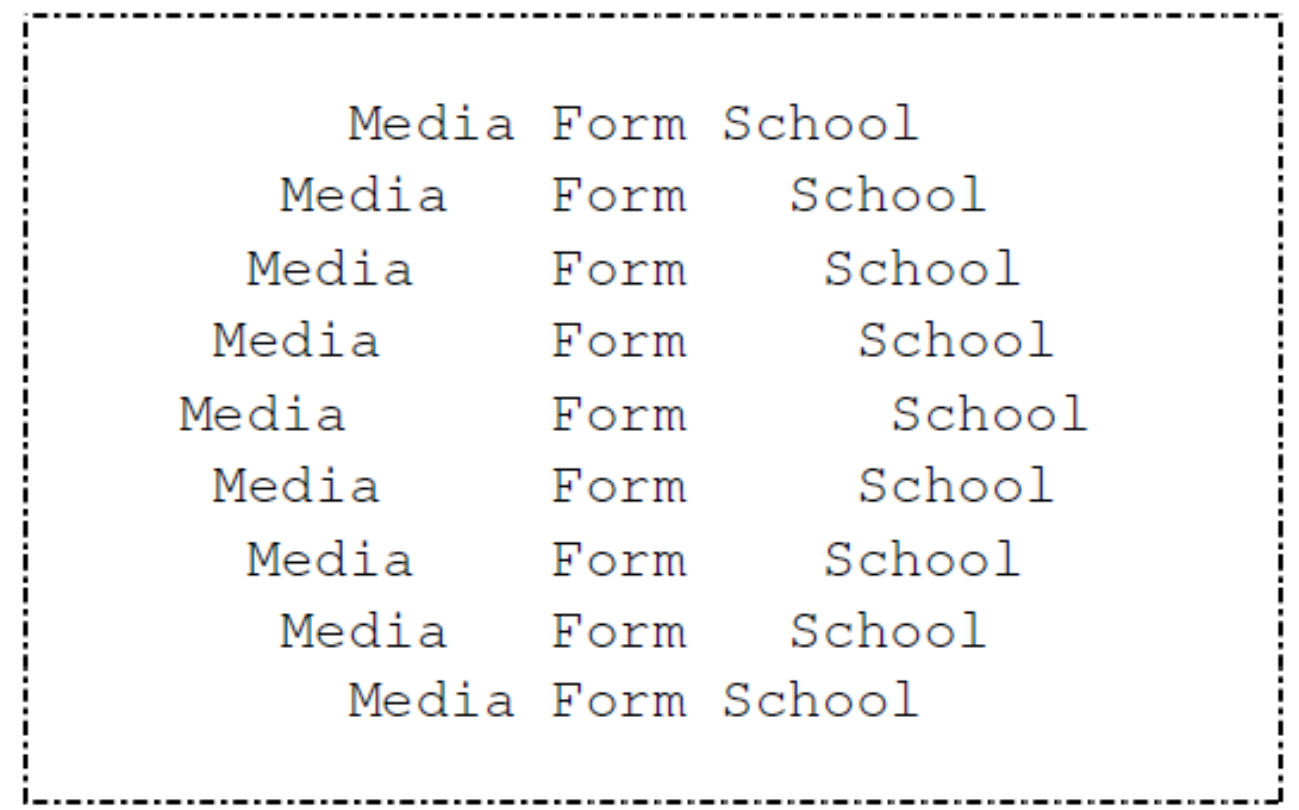

Figure 2: Chart «Media Form School» (illustration by the author).

If we regard Figure 2 as a text-image in the sense of conceptually oriented visual poetry, new interpretations open up. As graphic material, the multiple character strings of «Media Form School» can stage an event in perception, so to speak, which consists in the paradox of presence and absence. Already the spatial proximity of the individual expressions can be interpreted as coexistence, cooperation, conflict, interdependence or entanglement. The reading-image is outwardly and inwardly open, and from self-referential points of view it is of a medial character itself. Thus, the difference between a finite string of characters and open definitions offers diverse interpretations as to relations between idea and visual appearance, as well as regarding conceptual and perceptive processes.

Examples of concrete poetry can be very helpful in disrupting and questioning routine use of language and symbols as a matter of course. By making visible the material appearance of something thought and the transition from sign to idea, categories of thinking take center stage in an elementary way. In this way, formal education and media education are given new perspectives for the critical examination of linguistic and symbolic forms. ${ }^{8}$

8 Similarly, different forms of rationality can be critiqued following poly-contextural logics. For example, "The Chinese Challenge» team-blog deals with the connection between written form and form of thought, and with the philosophical question: «to what extent the Chinese script may correspond to a specific form of rationality?» (see http://www.thinkartlab.com/CCR/rudys-chinese -challenge.html). Particular aspects of this subject have also been examined from a linguistic point of view (see Boroditsky 2001). For a brief introduction to «poly-contexturality» see Günther (1973). 


\subsection{Considerations on media activism}

"So, does the current media pedagogy have to be so well-behaved all the time?», Ben Bachmair asked recently during a discussion at a conference on "Media Knowledge - Education: Free educational media and digital archives.»" Well, school pedagogy and academic pedagogy in general - not only in Germanspeaking areas - occasionally have to put up with similar questions. It may not be surprising that different forms of ideology, of the narrow limitation of topics, of benevolent subordination and casual, opportunistic argumentation can be found also and especially among those who want to oblige others to very specific notions of criticism or sell these notions as «the one and only truth.» After all, there are many paradoxes that have figured in pedagogy since the theorization of educational action began. However, this does not help those bright minds who cannot or will not be satisfied with rhetoric about innovation motivated by educational economy, with e-learning as a subsidiary tool of technology-oriented administrative bureaucracy, or with demands of educational policy that neglect the role of media.

Some options for expanded, less «well-behaved» perspectives of thinking and acting between the poles of other-directedness and self-determination present themselves in the wake of media-activist forms of intervention. I have already published some considerations on this (see Hug 2011b), which I want to use here once again and further differentiate.

On the one hand, «media activism can be considered a collective term for the diverse forms of politically or artistically motivated media use for protest and participation aimed at changing society. The different orientations, languages, methods and goals of more recent forms of media activism ${ }^{10}$ can each be described in detail. From a historical perspective, media activism can be described in the sense of addressing «media history as the history of resistance» (Sützl 2011, 9), regarding both its content as well as it being a «mode of media history which makes it possible to understand media activism in its political dimension» (ibid.). From a systematic standpoint, the different forms of media activism can be analyzed as variations in the sense of Goodman und Elgin (1989, 93-113). The concrete manifestations can be examined on the basis of three aspects: (1) unconventional use of media, (2) strengthening of minority developments and (3) cognitive autonomy in resistant subcultures (see Hug 2011b, 3-4).

Sporadically, media-activist efforts are taken up in the context of school. The example of graffiti shows how different such references can be. On the one hand, «graffiti education» refers to a prophylactic or preservative programs aiming at the

\footnotetext{
9 «Medien - Wissen - Bildung: Freie Bildungsmedien und Digitale Archive»; see http://medien.uibk ac.at/mwb2013.

10 Consider for example culture jamming, hacktivism, alternative media, tactical (bio-)media, electronic civil disobedience, electronic street theatre, swarming, anti-corporate saboteurs, etc.
} 
local or regional prevention of media-activist interventions. ${ }^{11}$ On the other hand, there are lesson plans and guidelines for lesson design readily available which emphasize the use of software and the deconstruction of writing (see Schuster 2004) or contributions to the design of the school building (see Deisenhofer 2009). Differentiated socio-critical considerations of graffiti as an informal educational context receive relatively scant attention. Such a broad perspective is what Richard Christen has in mind when he writes: "Although seldom recognized as such, graffiti crews are also educational organizations that promote valuable learning among their members» (Christen 2003, 57). He argues that

graffiti education both parallels and diverges from the teaching of these traditional institutions, functioning paradoxically as both a status quo and transgressive organization. Graffiti provides poor and disadvantaged adolescents with knowledge, skills, and values important for success in the mainstream. At the same time, it bonds young people to their urban neighborhoods, empowering them to challenge the dominant society and to transform rather than escape their communities. (Christen 2003, 57)

Such a point of view goes far beyond the occupation in the classroom with graffiti as a historical or contemporary art form, as a case of application for software exercises, or as a decoration on specifically designated school walls. Such a point of view invites fundamental reflection on the capacity of different forms of organization, on the legitimation of didactics and learning arrangements, or on the relationship between formal and informal contexts. This can occur in areas of tension, which are linked, for instance, to action orientations in contexts of media activism and school (see Table 1). In view of the fact that creativity, critical thinking, independent problem solving, responsible action, and the competent handling of media are (or should be) taken seriously in many places as interdisciplinary guiding principles of education, these aspects could play a similarly prominent role in both contexts (of media activism and school). In actuality, however, we can discern considerable differences. In the context of learning and teaching in school, creativity, critical thinking, independent problem-solving, etc. are far more oriented to stabilizing and continuing the educational institution and passing on sociocultural programs, and not least the assimilation to these programs and participation in social institutions.

11 See for example http://www.warnergroup.com.au/graffiti-awareness or http://www.riversideca.gov /graffiti/education.asp. 


$\begin{array}{lll}\text { Destabilization } & - & \text { Stabilization } \\ \text { Discontinuity } & - & \text { Continuity } \\ \text { Revolution } & - & \text { Evolution (reform) } \\ \text { Subversion } & - & \text { Transparency } \\ \text { Disobedience } & - & \text { Obedience } \\ \text { Self-vill } & - & \text { Solidarity } \\ \text { Resistance } & - & \text { Assimilation } \\ \text { Refusal } & & \end{array}$

Table 1: Action orientation in contexts of media activism and school

In my opinion, these are relative, not absolute opposites. It may be true that the left column in Table 1 tends to be associated primarily with media-activist contexts, and the right column with school. However, such items as self-will, disobedience and refusal may gain weight in the latter context in a way that implies that the viability of conventional arrangements is coming to an end. Conversely, conventional concerns of political participation or a high pressure for assimilation from within the group may also be important in media-activist contexts. Especially when critical notions of pedagogy and (media) didactics are conceived as media-activist ones (see Giroux 2001), the differences on an individual basis may become blurry or noticeable only in details. In most cases of action-oriented didactics in school contexts, considering the mentioned areas of tension and using media-activist examples will lead to expanded action orientations and perspectives for reflection.

\section{Medial forms - Considerations on the application of media-theoretical differentiations in contexts of school pedagogy}

In educational and school pedagogy, forms have always played an important role, even though the concept of «form» is hardly ever made explicit. ${ }^{12}$ While variations on school types, teaching methods, forms of working or social forms are readily distinguished, discourse on media forms mostly relates to media technologies.

\footnotetext{
12 See for example Plato's notion of idea/form (Greek idea, eidos) as that which truly «is», in contrast to sensorily things perceptible and transient things; see also Plato's elitist stage model of limited possibilities of rising to the idea of the good and true in the education state. Finally, see the formal stages of instruction of Johann Friedrich Herbart (1776-1841), or Wolfgang Klafki's distinction between formal, material and categorical theories of education.
} 
In the following, I want to point out how such conceptual differentiations can be reassessed and expanded in the light of contrasting theoretical perspectives.

If discourse on education and upbringing mentions forms in regard to media, it usually does so through unsystematic or illustrative lists of media ${ }^{13}$ or with the differentiation between primary, secondary and tertiary media that Harry Pross introduced in the 1970s (see Pross 1972, 10ff.)14 and that still serves as an essential point of reference, for instance in handbooks (see Kommer and von Gross 2012). Some authors have developed specific, theoretically founded concepts which can be applied to school-pedagogical contexts. Bachmair for example uses perspectives from life-world, socialization and semiotic theory as a background and regards forms of media as cultural products which are relevant in socialization processes to the degree that these processes are dominant (see Bachmair 2007). More abstract perspectives can be developed against the background of the distinction between medium and form in the theory of Niklas Luhmann, which conceives of media as a number of loosely linked elements that make forms perceivable as a number of firmly linked elements. Along these lines, Dirk Baecker understands «education [to be] in the medium of intelligence» (2006), distinguishing his position from Luhmann's view of the "curriculum vitae» as a communication medium of education (Baecker 2006, 22-23). It may be true that this abstract sociological perspective offers advantages, as he writes:

It keeps its distance from educational science's ideologies of profession, and instead has recourse to attempts at feeding the modalities of differentiating the educational system back to social structures and their transformation. It does not adhere to the necessity of a reflection theory to confirm and foster the identity of the system to which it is proper, but instead focuses on the difference of the system in the context of society. There is plenty of cause for this since the conversion from print society to computer society does not leave the educational system untouched. (Baecker 2006, 25)

Apart from the advantage that contrasting perspectives in general facilitate insights which cannot be gained in the course of analyses that are inherent in a given discourse, this approach does not solve the problem of systematic coupling (Anschlussfähigkeit). Even if the choice of a communication medium as the primary focus for addressing a problem is well-founded, there must be a reflection on

\footnotetext{
13 Such lists contain media like books, blackboards, photographs, film, DVD/CD-ROM, audio, video, Internet, learning platforms, smart boards, WWW, Java, Flash, Web 2.0, social media, etc.

14 Recently, some have suggested quaternary media as a fourth option. These media are characterized by communications who use networked computers and have new interactive possibilities. Accompanying the digitalization and networking, the traditional roles of sender and receiver become varied and modified.
} 
contextual dimensions of the selected frame of reference if «non-fundamentalist basic concepts» (Heyting 2001) are the goal. ${ }^{15}$ This seems all the more important not only for educational systems and their academic study, but also other systems and other no less undisciplined disciplines find themselves in a crisis of orientation. Questions about limitations occur in connection with dynamics of pedagogization, but also of sociologiziation, psychologization or mediatization.

There is one theory of medial forms from Rainer Leschke (2010) which can be connected with cognitive philosophy, systems theory, information ecology, media ecology, social ecology, theories of action and application orientation. Discussing different notions of form, and continuing Ernst Cassirer's philosophy of symbolic forms, Leschke has developed a medium-range theory which makes the stability and dynamics of the medialized constellations adequately describable. These new constellations demand a new knowledge about forms, which is significant in the context of school types and teaching methods, among other things.

While the complex of interpretative knowledge, identity construction and self-concept of the humanities was still largely based on the media-historical constellation of printing, which resulted in general reading ability and competence in meaning creation, the current medial constellations, with augmented reality, the intermedial migration of forms, and the unnoticeable transitions between entertainment media and functional media, require and generate first and foremost knowledge about forms. (Leschke 2008, 49)

This knowledge can relate to forms of play, narrative forms or interface logics, for example, but also to individual forms like menu control (e.g. pull-down menu vs. ensemble). What is important here is that such forms are now applied in different media constellations and not only in single media. If we accept that it has generally become problematic to orient the internal differentiation of knowledge systems by individual media and their dispositifs (see Leschke 2010, 303), then this is also valid for knowledge acquired at school, in the sense of book learning, and then transversal and transmedial dimensions also assume significance in contexts of school pedagogy.

Leschke $(2010,305)$ has suggested focusing on medial forms as classification tools in the transversally linked media system. His theory of medial forms (Leschke 2008) offers manifold possibilities of describing and analyzing the dynamics of forms and the exchange processes between different media as well as between mass media and art. In regard to media theory, it is compatible with more limited concepts of pattern formation (Winkler 2012), more broadly conceptualized theories of media

15 Compare this to the discourse on epistemological contextualism (DeRose 1999 and 2006) and van Goor et al. (2004). 
dynamics (Rusch 2007) and the theory of media culture of Siegfried J. Schmidt (2008). In contrast to comparatively concrete or very abstract concepts (see Figure 3), the theory of medial forms can be applied flexibly. It allows diverse and differentiated analyses of open structural formations in areas of tension between formal-aesthetic, content-related and temporal dimensions.

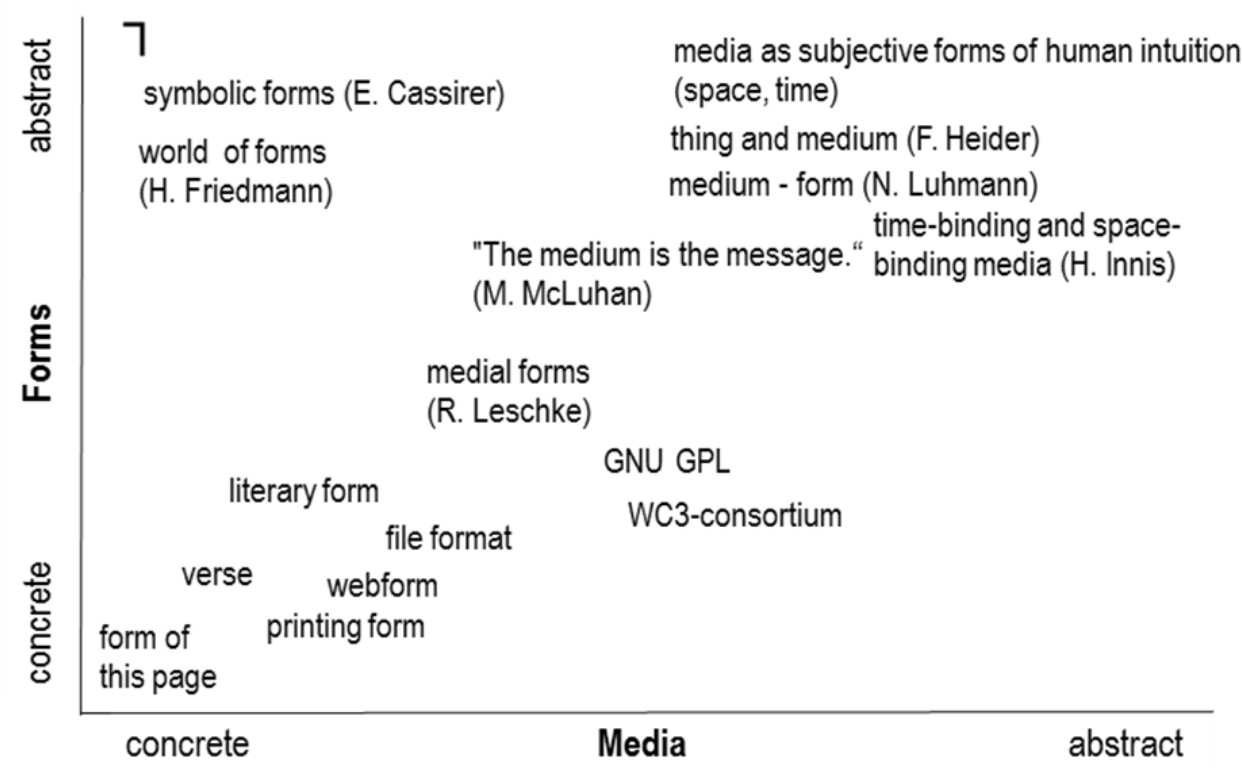

Figure 3: Forms and media: Scopes and selected examples (illustration by the author).

The knowledge of medial forms and their analysis is also relevant to the examination and shaping of cultural, social and education-related concepts and practices. Here are some examples which are significant to schools:

- Testing of school knowledge, evaluation based on the school grade system, group work, cartoons in textbooks, brainstorming, mindmaps (concept maps), etc.

- Hip-hop rhythms for learning purposes, webquests, creation of sequences of learning/teaching with freely usable game engines, collaborative writing with Wikis, etc.

In a transversally integrated media system, the key function of medial forms comes into effect in a double sense as the «material of media communication» and as «the ideation of media technology» (Leschke 2010, 300), in a way that steers clear of views of isolated phenomena that are restricted by either technological determinism or culturalism. In terms of processes of school learning and education, these forms can serve as objects for reflection, means and constitutive moments. On the one hand, they represent media-cultural resources for educational processes par excellence. 
On the other hand, on meso- and macro-theoretical levels they offer reference points for clarifying dynamics of de-/recontextualization and of connections with pedagogization formulas and problems of reproduction (see Veith 2003, 183-201). Yet there is no reason to reduce the consequences for school and media pedagogy to elitist or middle-class perspectives, or to pass on a demand for education as a «(European, progressive, civically administrated regional expression» (Faßler 2010). On the contrary: If notions, processes and outcomes of education are considered as moments of the (co-)evolution of medialized constellations, the particularities of aspects of written culture and book culture and their «self-evident» character become comprehensible.

In view of these considerations, the focus cannot solely be on further differentiating «literality» as an educational task (see Bertschi-Kaufmann u. Rosebrock 2009) or expanding the imagery of literacy with regard to ever new «literacies» (see Hug 2012). The point is rather to spell out the relationship of literality, numerality, pictoriality, and orality in the formation process of forms. ${ }^{16}$ Hence, broadened perspectives for reflection and action become possible which can be brought to fruition particularly in school contexts. If in the process different medial forms are made explicitly clear in their relative significance and function in contexts of communication culture, this also enables for example widened perspectives of establishing principles of media education for socially disadvantaged youth (see Niesyto 2004, 129).

As regards the use of conceptual and creative leeway between the "empty space» (Brook 1968) and elaborately designed didactics of all kinds, it seems reasonable also to take into account expanded perspectives beyond prevalent didactic arrangements and scenarios. In particular, more recent theories of design (see Krippendorff 2006) presents starting points for conceptual expansions.

\section{Conclusion}

This plea for expanded action orientations and reflective perspectives may meet with skepticism from school pedagogy for several reasons. Even if interdisciplinary considerations play their part in the context of debates on school reform and innovation (see Berkemeyer et al. 2010), application-oriented concerns (for example Schnebel and Keller 2011) generally get more attention in school development, and not only among the practitioners, than deliberations on theoretical principles. Although since the 1960s approaches based on (socio-)psychology, sociology, social sciences and cultural studies have in many respects attracted interest in the field of pedagogical research into schools, questions of internal and external legitimation have not become obsolete in the process. Quite the contrary: The

\footnotetext{
16 A systematic examination of this relationship after the digital turn (Kossek and Peschl 2012), taking
} into account the scattered points of reference in relevant scientific discourses is still a desideratum. 
traditional monopoly on education and information held by schools has become shaky, promises about advancement and the future have become questionable, and in many countries, economically oriented educational measurement and media-based administrative bureaucracies have long gained primacy over education-theoretically motivated or pedagogically oriented action in schools and classrooms. Finally, neither media-phobias fed by a sense of neuro-mission, nor media-euphorias distorted by learning technology nor sporadically extended forms of literacy ${ }^{17}$ contribute to an adequate understanding of contemporary media and information ecologies.

It may be true, as Jürgen Oelkers et al. (2008) write in their reply to historical experiences with quality assurance in schools, that the introduction of standards has always been meant to improve quality (17) and that on the level of didactic teaching material

innovations were and are disseminated quickly, without respect to national borders. It is no coincidence that usefulness in the classroom is a crucial prerequisite for effective implementation. Tools, media and technologies, in this sense know-how which crystallizes in tools, can be conveyed much more easily than relatively abstract, language- and culture-bound theories which require complex interpretation. (Oelkers et al. 2008, 19)

The theory of medial forms not only demands such complex interpretive work, it calls for a differentiated historical and systematic examination of the medial constellations of the educational claims, concepts and practices of schools. As in this process media come to the fore as a historically situated grammar of our educational conditions, the result is that (a) only now do convergent and divergent dynamics become adequately understandable in the international comparison of educational systems; (b) relatively stable, redundant structures in medial change become comprehensible in their significance for developments in communication culture in general and school culture in particular, (c) chances for school developments beyond innovation rhetoric and resistance to reform become visible and justifiable in a differentiated manner, and (d) challenges in view of globalizing educational developments and media ecologies become easier to deal with.

It remains to be seen to what extent these and similar media-theoretically informed suggestions will be taken up, ignored or rejected by school theory and applicationoriented school pedagogy. So far, proposals for «media education in new cultural spaces» (Medienbildung in neuen Kulturräumen, Bachmair 2010) have sporadically

17 For example art literacy, computer literacy, consumer literacy, digital literacy, diversity literacy, ecological literacy, emotional literacy, environmental literacy, film literacy, food literacy, geographical literacy, health literacy, information literacy, library literacy, multicultural literacy, numerical literacy, visual literacy, sexual literacy, television literacy, etc. 
led to school trials and pilot projects, but in large part school is developed along the lines of «typographic educational architectures» (Böhme 2006, 114). However, the exploration of creative, conceptual and critical-reflexive latitude, even in institutionalized education, does not necessarily have to be restricted to literacybased forms of the communicative stabilization of learning cultures.

The elaborations in this paper show that expansions are conceivable, if nothing else. To what extent they are in fact viable may remain open for now in view of the challenges related to innovative perspectives between the poles of economically inspired (schoolifications and calls for room for «de-schooled) learning - from Paolo Freire and Ivan Illich to user-generated education. ${ }^{18}$ This much should have become clear, however: The plea for expanded action orientations and perspectives for reflection also refers to the range of established functions of schools, among them administration, allocation, integration, reproduction of the social structure, selection, socialization, qualification, and the passing on of culture and knowledge. On the one hand, these functions are to be critically reassessed under the conditions of medialization. On the other, what also matters is knowledge about forms of schools and teaching and their functions, and thus no less than enlightenment about the medialized constellations in which they appear. If we take this seriously, it also means reevaluating traditional notions of how education and enlightenment are related, and «Rethinking the Enlightenment» (Elkana 2011), taking into account that all knowledge, not just that acquired in school, is contextbound and medialized.

\section{References}

Atkins, Daniel E., John Seely Brown and Allen L. Hammond. 2007. «A Review of the Open Educational Resources (OER) Movement: Achievements, Challenges, and New Opportunities. Report to The William and Flora Hewlett Foundation.» Accessed Sept. 23, 2014. http://www.hewlett.org/uploads/files /ReviewoftheOERMovement.pdf.

Bachmair, Ben. 2007. «Mediensozialisation - die Frage nach Sozialisationsmustern im Kontext dominanter Medienformen.» In Jahrbuch Medienpädagogik 6: Medienpädagogik - Standortbestimmung einer erziehungswissenschaftlichen Disziplin, ed. Werner Sesink, Michael Kerres, and Heinz Moser, 118-143. Wiesbaden: VS Verlag.

Bachmair, Ben, ed. 2010. Medienbildung in neuen Kulturräumen: Die deutschsprachige und britische Diskussion. Wiesbaden: VS Verlag.

Baecker, Dirk. 2006. «Erziehung im Medium der Intelligenz.» In Beobachtungen des Erziehungssystems: Systemtheoretische Perspektiven, ed. Yvonne Ehrenspeck and Dieter Lenzen, 26-66. Wiesbaden: VS Verlag.

\footnotetext{
18 See http://usergeneratededucation.wordpress.com/.
} 
Bauer, Matthias, and Christoph Ernst. 2010. Diagrammatik: Einführung in ein kulturund medienwissenschaftliches Forschungsfeld. Bielefeld: Transcript.

Berkemeyer, Nils, Wilfried Bos, and Harm Kuper, Eds. 2010. Schulreform durch Vernetzung: Interdisziplinäre Betrachtungen. Münster: Waxmann.

Bertschi-Kaufmann, Andrea, and Cornelia Rosebrock, Eds. 2009. Literalität: Bildungsaufgabe und Forschungsfeld. München, Weinheim: Juventa.

Blankertz, Stefan. 2013. Pädagogik mit beschränkter Haftung: Kritische Schultheorie. Berlin: Books on Demand.

bm:ukk. 2009. "Grundsatzerlass «Ganzheitlich-kreative Lernkultur in den Schulen» des Bundesministeriums für Unterricht, Kunst und Kultur.» http://www.bmukk .gv.at/ministerium/rs/2009_15.xml.

bm:ukk. 2012. "Medienerziehung: Grundsatzerlass des Bundesministeriums für Unterricht, Kunst und Kultur.» http://www.bmukk.gv.at/medienpool/5796 /medienerziehung.pdf.

Böhme, Jannette. 2006. Schule am Ende der Buchkultur: Medientheoretische Begründungen schulischer Bildungsarchitekturen. Bad Heilbrunn: Klinkhardt.

Boroditsky, Lera. 2001. "Does Language Shape Thought? Mandarin and English Speakers' Conceptions of Time.» Cognitive Psychology 43: 1-22. http://www -psych.stanford.edu/ lera/papers/mandarin.pdf.

Braidotti, Rosi. 2013. The Posthuman. Malden, MA: Wiley.

Brook, Peter. 2004. Der leere Raum. Berlin: Alexander Verlag. English edition 1968.

Bublitz, Hannelore, Roman Marek, Christina L. Steinmann, and Hartmut Winkler. 2010. Automatismen. München: W. Fink.

Butcher, Neil et al., eds. 2011. A Basic Guide to Open Educational Resources. Commonwealth of Learning. http://www.col.org/PublicationDocuments/Basic -Guide-To-OER.pdf.

Christen, Richard S. 2003. «Hip Hop Learning: Graffiti as an Educator of Urban Teenagers.» Educational Foundations 17(4): 57-82. http://www.graffiti.org/faq/ graffiti_edu_christen.html.

Ciompi, Luc. 1997. Die emotionalen Grundlagen des Denkens: Entwurf einer fraktalen Affektlogik. Göttingen: Vandenhoeck \& Ruprecht.

Ciompi, Luc. (n.d.) «The concept of affect-logic.» http://www.ciompi.com/en /affect-logic.html.

Deisenhofer, Kathrin. 2009. "Graffiti.» http://www.lehrer-online.de/graffiti.php?s $\mathrm{id}=92322249759345487937546204620560$.

DeRose, Keith. 1999. "Contextualism: An Explanation and Defense.» In The Blackwell Guide to Epistemology, ed. John Greco and Ernest Sosa, 187-205. Oxford: Basil Blackwell.

DeRose, Keith. 2006. "Contextualism in Epistemology: A Bibliography.» http:// pantheon.yale.edu/ kd47/Context-Bib.htm. 
Elkana, Yehuda. 2011. «Rethinking the Enlightenment.» Approaching Religion 1(2). http://ojs.abo.fi/index.php/ar/article/view/117/97.

Faßler, Manfred. 2008. Der infogene Mensch: Entwurf einer Anthropologie. München: W. Fink.

Faßler, Manfred. 2009. Nach der Gesellschaft: Infogene Welten - anthropologische Zukünfte. München: W. Fink.

Faßler, Manfred. 2010. «Sonderzone Bildung? Ein Abschied.» Recherche: Zeitung für Wissenschaft 4: 3-6.

Friesen, Norm, and Theo Hug. 2009. "The Mediatic Turn: Exploring Concepts for Media Pedagogy.» In Mediatization: Concept, Changes, Consequences, ed. Knut Lundby, 63-83. Frankfurt am Main: Lang.

Giroux, Henry A. 2001. Theory and Resistance in Education: Towards a Pedagogy for the Opposition. Westport/London: Bergin and Garvey. First edition 1983.

Goodman, Nelson, and Catherine Z. Elgin. 1989. Revisionen: Philosophie und andere Künste und Wissenschaften. Frankfurt am Main: Suhrkamp. English edition 1988.

Gruschka, Andreas. 2002. Didaktik - das Kreuz mit der Vermittlung. Wetzlar: Büchse der Pandora.

Günther, Gotthard. 1973. "Life as Poly-Contexturality.» In Wirklichkeit und Reflexion, Festschrift für Walter Schulz, ed. Helmut Fahrenbach, 187-210. Pfullingen: Neske http://www.vordenker.de/ggphilosophy/gg_life_as_polycontexturality. pdf.

Härtel, Peter, Ulrike Greiner, Stefan Hopmann, Bettina Jorzik, Marlies Krainz-Dürr, Arthur Mettinger, Martin Polaschek, Michael Schratz, Martina Stoll, and Willi Stadelmann. 2010. «Lehrerlnnenbildung NEU: Die Zukunft der pädagogischen Berufe. Die Empfehlungen der ExpertInnengruppe.» http://www.bmukk.gv.at/ medienpool/19218/labneu_endbericht.pdf.

Hettinger, Jochen. 2008. E-Learning in der Schule: Grundlagen, Modelle, Perspektiven. München: KoPäd.

Heyting, Frieda G. 2001. "Antifoundationalist Foundational Research: Analysing Discourse on Children's Rights to Decide.» In Methods in the Philosophy of Education, ed. Frieda G. Heyting, Dieter Lenzen and John White, 108-124. London: Routledge.

Hierdeis, Helmwart. 2009. "Selbstreflexion als Element pädagogischer Professionalität.» http://www.uibk.ac.at/iezw/texte/hierdeis.pdf.

Hopmann, Stefan, Ulrike Greiner, Roland Fischer, and Ralph Grossmann. 2010. «Ergänzende Expertise zu LehrerInnenbildung NEU: Die Zukunft der pädagogischen Berufe.» http://www.bmukk.gv.at/medienpool/19694 lexpertise_lehrerinn.pdf. 
Horn, Klaus-Peter, Heidemarie Kemnitz, Winfried Marotzki, and Uwe Sandfuchs. Eds. 2011. Klinkhardt Lexikon Erziehungswissenschaft (KLE). 3 vols. Bad Heilbrunn/Stuttgart: Klinkhardt/UTB.

Hug, Theo. 2002. «Phantome gibt's wirklich - oder? Konzeptionelle Gesprächsangebote zu einem vielgestaltigen Phänomenbereich.»In Phantom Wirklichkeit, ed. Theo Hug and Hans-Jörg Walter, 21-39. Baltmannsweiler: Schneider-Verlag Hohengehren.

Hug, Theo. 2011a. «Die Paradoxie der Erziehung: Theo Hug über den Konstruktivismus in der Pädagogik.» In Schlüsselwerke des Konstruktivismus, ed. Bernhard Pörksen, 463-483. Wiesbaden: VS.

Hug, Theo. 2011b. «Sondierungen im Spannungsfeld von Medienaktivismus und handlungsorientierter Medienpädagogik.» In Medienimpulse: Beiträge zur Medienpädagogik. http://www.medienimpulse.at/articles/view/308.

Hug, Theo. 2012. «Media Competence and Visual Literacy: Towards Considerations Beyond Literacies.» Periodica Polytechnica: Social and Management Sciences 20(2): 115-125. http://www.pp.bme.hu/so/2012_2/pdf/so2012_2_06.pdf.

Kerres, Michael, and Richard Heinen. 2014. "Open Educational Ressources und schulisches Lernen: Das Zusammenwirken von Plattformen für Lernressourcen in informationell offenen Ökosystemen.»In Medien - Wissen - Bildung: Freie Bildungsmedien und Digitale Archive, ed. Petra Missomelius, Wolfgang Sützl, Theo Hug, Petra Grell, and Rudolf Kammerl. Innsbruck: Innsbruck University Press.

Kommer, Sven, and Friederike von Gross. 2012. "Medienformen.»In Klinkhardt Lexikon Erziehungswissenschaft, vol. 2, ed. Klaus-Peter Horn, Heidemarie Kemnitz, Winfried Marotzki, and Uwe Sandfuchs, 355-356. Bad Heilbrunn: Klinkhardt UTB.

Kossek, Brigitte, and Markus F. Peschl, eds. 2012. «Digital turn`? Zum Einfluss digitaler Medien auf Wissensgenerierungsprozesse von Studierenden und Hochschullehrenden. Vienna: Vandenhoeck \& Ruprecht, V\&R Vienna University Press.

Krippendorff, Klaus. 2006. The Semantic Turn: A New Foundation for Design. Boca Raton, London, New York: Taylor \& Francis CRC.

Leschke, Rainer. 2008. «Medienformen und Medienwissen: Zwischen Interpretation und Formerkennung.»In Media, Knowledge \& Education: Exploring New Spaces, Relations and Dynamics in Digital Media Ecologies, ed. Theo Hug, 36-50. Innsbruck: Innsbruck University Press.

Leschke, Rainer. 2010. Medien und Formen: Eine Morphologie der Medien. Konstanz: UVK.

Leschke, Rainer. 2013. «Mutmassungen über Mediendynamiken: Zur Logik medienkultureller Entwicklungen.» In Medien - Wissen - Bildung: Freie 
Bildungsmedien und Digitale Archive, ed. Petra Missomelius, Wolfgang Sützl, Theo Hug, Petra Grell, and Rudolf Kammerl. Innsbruck: Innsbruck University Press.

Leschke, Rainer and Norm Friesen. 2014. «Education, Media and the End of the Book: Some Remarks from Media Theory.» MedienPädagogik 24 (3. Oct.): 183203. http://www.medienpaed.com/24/\#leschke_friesen 1410.

McCulloch, Gary, and David Crook, eds. 2008. The Routledge International Encyclopedia of Education. London/New York: Routledge.

Niesyto, Horst. 2004. "Medienbildung mit Jugendlichen in Hauptschulmilieus.» In Informelle Bildung Online: Perspektiven für Bildung, Jugendarbeit und Medienpädagogik, ed. Hans-Uwe Otto and Nadja Kutscher, 122-136. Weinheim, München: Juventa.

Oelkers, Jürgen, and Kurt Reusser, in collaboration with Esther Berner, Ueli Halbheer and Stefanie Stolz. 2008. Expertise: Qualität entwickeln - Standards sichern - mit Differenz umgehen. Bonn/Berlin: Schriften des Bundesministeriums für Bildung und Forschung (BMBF). http://www.bmbf.de/pub/bildungsforschung _band_siebenundzwanzig.pdf.

Pross, Harry. 1972. Medienforschung: Film, Funk, Presse, Fernsehen. Darmstadt: Habel.

Rusch, Gebhard. 2007. «Mediendynamik: Explorationen zur Theorie des Medienwandels.» Navigationen: Zeitschrift für Medien- und Kulturwissenschaften 7(1): 13-93.

Schmidt, Siegfried J. 1999. "Blickwechsel: Umrisse einer Medienepistemologie.» In Konstruktivismus in der Medien- und Kommunikationswissenschaft (= Delfin 1997), ed. Gebhard Rusch and Siegfried J. Schmidt, 119-145. Frankfurt am Main: Suhrkamp.

Schmidt, Siegfried J. 2008. «Media Philosophy: A Reasonable Programme?»In Philosophy of the Information Society: Proceedings of the 30th International Ludwig Wittgenstein Symposium Kirchberg am Wechsel, Austria 2007, vol. 2, ed. Herbert Hrachovec and Alois Pichler, 89-105. Frankfurt: Ontos.

Schnebel, Stefanie, and Alois Keller. 2011. «Herausforderungen in der Schulentwicklung: Systematische Einführung.» In Herausforderung Schulinnovation, ed. Stefanie Schnebel and Alois Keller, 1-7. Baltmannsweiler: Schneider Verlag Hohengehren.

Schnider, Andreas, Roland Fischer, Peter Härtel, Stefan Hopmann, Christa Koenne, Erwin Niederwieser, and Cornelia Wurstmann. 2011. "PädagogInnenbildung neu: Die Zukunft der pädagogischen Berufe. Empfehlungen der Vorbereitungsgruppe.» Final report. Bundesministerium für Unterricht, Kunst und Kultur und Bundesministerium für Wissenschaft und Forschung, Vienna. http:// www.bmukk.gv.at/medienpool/20840/pbneu_endbericht.pdf. 
Schuster, Uli. 2004. "Graffiti mit Photoshop: Eine Unterrichtseinheit zur Umgestaltung, Dekonstruktion von Schrift in der Mittelstufe des Gymnasiums.» http://www.kusem.de/konz/su32/graf.htm.

Sützl, Wolfgang. 2011. «Medien des Ungehorsams: Zur Geschichtlichkeit von Medienaktivismus.» http://www.medienimpulse.at/articles/view/290.

Tippelt, Rudolf, and Bernhard Schmidt, eds. 2010. Handbuch Bildungsforschung. Third edition. Wiesbaden: VS.

Urry, John. 2000. Sociology Beyond Societies: Mobilities for the Twenty-First Century. New York: Routledge.

Van Goor, Roel, Frieda G. Heyting, and Gert-Jan Vreeke. 2004. «Beyond Foundations: Signs of a New Normativity in Philosophy of Education.» Educational Theory 54 (2): 173-192.

Veith, Hermann. 2003. "Lernkultur, Kompetenz, Kompetenzentwicklung und Selbstorganisation: Begriffshistorische Untersuchungen zur gesellschaftlichen und pädagogischen Konstruktion von Erziehungswirklichkeiten in Theorie und Praxis.» In Was kann ich wissen? Theorie und Geschichte von Lernkultur und Kompetenzentwicklung(= QUEM-report, SchriftenzurberuflichenWeiterbildung 82), ed. Arbeitsgemeinschaft Betriebliche Weiterbildungsforschung e.V./ Projekt Qualifikations-Entwicklungs-Management, Berlin, 179-229. http://www .abwf.de/content/main/publik/report/2003/Report-82.pdf.

Winkler, Hartmut. 2012. "Schemabildung: Eine Maschine zur Umarbeitung von Inhalt in Form.» In Schemata und Praktiken, ed. Tobias Conradi, Gisela Ecker, Norbert Otto Eke, and Florian Muhle, 15-35. München: W. Fink. 